\title{
PRAKTIK PERKAWINAN DIBAWAH UMUR DAN DAMPAKNYA TERHADAP KEHARMONISAN RUMAH TANGGA DI KABUPATEN BOALEMO
}

\author{
Jusuf A. Lakoro dan Zulkarnain Suleman \\ Email: lakoroyusuf@gmail.com \\ Tahun 2018
}

\begin{abstract}
ABSTRAK
Perkawinan dibawah umur di Kabupaten Boalemo umumnya terjadi pada anak-anak usia sekolah yang seharusnya masih merasakan dunia pendidikan dan menikmati indahnya masamasa muda, namun harus berakhir dengan perkawinan diusia yang masih sangat muda dengan mengorbankan masa depan dan pendidikannya. Penelitian ini untuk menemukan, mengungkap dan menggambarkan praktik perkawinan anak dan dampaknya di Kabupaten Boalemo.

Tesis ini merupakan penelitian lapangan, yang dilakukan di Kabupaten Boalemo yang tersebar di 6 Kecamatan. Penelitian ini menggunakan analisis kualitatif, dengan cara mengumpulkan data-data, didalami, dikaji, dipahami dan disimpulkan dengan cara deskriptif untuk mendapatkan keakuratan data. Pendekatan penelitian yang digunakan adalah pendekatan yuridis sosiologis yaitu melihat fenomena sosial dalam masyarakat yang kemudian dikaitkan dengan aturan yang berlaku.

Berdasarkan hasil penelitian, ditemukan realitas yang terjadi dalam praktik perkawinan diibawah umur antara lain bentuk perkawinan dibawah umur yang cukup beragam antara lain; dilaksanakan berdasarkan hasil dispensasi nikah, rendahnya usia perkawinan, perkawinan dengan salah satu pasangan yang lebih tua, perkawinan hamil diluar nikah, perkawinan tanpa restu orang tua dan perkawinan tidak tercatat. Perkawinan dibawah umur juga telah berdampak terhadap keharmonisan rumah tangga, antara lain tidak tercapainya kesejahteraan jiwa, tidak tercapainya kesejahteraan fisik dan tidak tercapainya perimbangan ekonomi dalam rumah tangga. Perkawinan dibawah umur seharusnya mampu dibendung dengan ketegasan aturan baik undang-undang tentang perkawinan dan KHI maupun aturan adat yang berlaku di masyarakat Gorontalo. Selain itu pentingnya proses penyadaran, edukasi dan sosialisasi terhadap undang-undang perkawinan yang tidak lagi diketahui oleh anak-anak saat ini maupun terhadap bahaya perkawinan dibawah umur.
\end{abstract}

Kata Kunci: Perkawinan Dibawah Umur, Dampak, Dan Keharmonisan Rumah Tangga 


\section{A. Pendahuluan}

Perkawinan pada dasarnya membutuhkan kematangan usia dan tingkat kedewasaan, sebab usia dewasa seseorang pada hakekatnya mengandung unsur yang berkaitan dengan dapat atau tidaknya seseorang mempertanggungjawabkan atas perbuatan hukum yang telah dilakukannya, yang menggambarkan kecakapan seseorang untuk bertindak dalam lalu lintas hukum perdata. Hukum dalam lintas masyarakat menghendaki kematangan berpikir dan keseimbangan psikis yang pada orang belum dewasa masih dalam taraf permulaan sedangkan sisi lain pada anggapan itu ialah bahwa seseorang belum dewasa dalam perkembangan fisik dan psikisnya memerlukan bimbingan khusus. Karena ketidakmampuannya maka seseorang yang belum dewasa harus diwakili oleh orang yang telah dewasa sedangkan perkembangan orang ke arah kedewasaan ia harus dibimbing.

Perkawinan dibawah umur yang banyak terjadi di masyarakat, bukanlah sesuatu hal yang baru dan aneh, sebab aturan dalam undang-undang di Indonesia membolehkannya dan tidak ada pula larangan secara spesifik dalam aturan agama Islam, sehingga dengan mudah perkawinan dibawah umur ini bisa terjadi. Padahal perkawinan dibawah umur dibawah umur itu sebenarnya dilalui dengan cara yang tidak mudah, harus mendapatkan penolakan dari KUA karena batasan umur yang tidak cukup, harus mengikuti proses dispensasi di Pengadilan Agama dan banyak mengeluarkan biaya yang cukup membebani, namun pada akhirnya banyak yang tidak mampu bertahan lama.

Kematangan dan kedewasaan umur perkawinan sudah pasti menjadi salah satu faktor penyebab dari keretakan rumah tangga. Kebolehan perkawinan dibawah umur dalam UndangUndang Nomor 1 Tahun 1974 tentang Perkawinan tercantum dalam pasal 7 ayat (1) disebutkan bahwa ,perkawinan hanya diizinkan apabila laki-laki sudah mencapai umur 19 tahun dan perempuan mencapai umur 16 tahun $^{\circ}$ dan dalam ayat (2) disebutkan bahwa ,Dalam hal penyimpangan dalam ayat (1) dapat meminta dispensasi di pengadilan atau pejabat lain yang diminta oleh orang tua pihak pria atau wanita ${ }^{\circ}$. Pasal 7 ini merupakan salah satu solusi dari penyelesaian perkara perkawinan dibawah umur yang dilakukan dengan proses dispensasi nikah, hal ini secara tidak langsung membolehkan perkawinan dibawah umur itu dilakukan, sehingga ini memberikan peluang kepada siapapun yang ingin menikah meskipun umurnya belum layak untuk usia nikah.

Perkawinan dibawah umur yang banyak terjadi di Kabupaten Boalemo setiap tahunnya semakin naik angka pertumbuhannya untuk perkawinan yang tercatat dan telah melalui proses dispensasi nikah di Pengadilan Agama. Dalam data perkawinan yang ada di Kabupaten Boalemo sejak tahun 2010 sampai dengan tahun 2016, terdapat 59 perkawinan dibawah umur masing-masing di Kecamatan Mananggu 4 kasus, Kecamatan Botumoito 4 kasus, Kecamatan Tilamuta 14 kasus, Kecamatan Paguyaman 16 kasus, kecamatan Dulupi 12 kasus, Kecamatan Wonosari 8 kasus, dan Kecamatan Paguyaman Pantai 1 kasus. Kasus perkawinan dibawah umur di Kabupaten Boalemo yang terbanyak terjadi pada tahun 2016 
dengan jumlah perkawinan dibawah umur sebanyak 30 kasus. Dari data 59 kasus perkawinan dibawah umur yang telah didapatkan di Pengadilan Agama Tilamuta yang telah dikabulakan hasil permohonan dispensasi nikah ini yang kemudian telah di cocokkan dengan data perkawinan dibawah umur di KUA, maka penelitian ini di fokuskan pada 36 kasus yang tersebar di 6 Kecamatan (Tilamuta, Wonosari, Dulupi, Paguyaman, Mananggu, Botumoito). Umumnya perkawinan dibawah umur di Kabupaten Boalemo memang masih banyak yang dilakukan tidak sesuai dengan prosedur yang telah ditetapkan baik dalam aturan hukum Islam maupun aturan negara dalam hal ini Undang-Undang Perkawinan dan Kompilasi Hukum Islam (KHI). Proses perkawinan dibawah umur tidaklah semulus dan semudah yang dipikirkan oleh sebagian orang yang menjalaninya, baik dalam proses menuju perkawinannya maupun sesudah perkawinan itu berlangsung. Ada yang melakukannya hanya dalam keadaan terpaksa bahkan dipaksa karena merasa belum siap menikah dan mempertanggungjawabkan perbuatannya, terutama bagi pasangan yang telah hamil diluar nikah. Bahkan ada yang prosesnya hanya berupa kawin turun dan perkawinan yang tidak direstui orang tua dengan tujuan untuk dapat melanjutkan kembali pendidikan yang masih sementara dijalani dan menghindari pandangan buruk masyarakat.

Berdasarkan uraian latar belakang diatas, maka sangat layak untuk dilakukan penelitian terhadap Praktik Perkawinan dibawah umur dan dampaknya terhadap keharmonisan rumah tangga di Kabupaten Boalemo. Dengan harapan bahwa penelitian ini akan memberikan gambaran kepada masyarakat Kabupaten Boalemo tentang bagaimana praktik perkawinan dibawah umur khususnya yang berkaitan dengan bentuk perkawinan yang terjadi dan realitas kehidupan rumah tangga setelah perkawinan dibawah umur, selain itu penelitian ini diharapkan juga dapat mengurangi praktik perkawinan dibawah umur yang banyak terjadi di masyarakat Kabupaten Boalemo.

Berdasarkan uraian latar belakang diatas dapat diangkat permasalahan yang akan diteliti sebagai berikut:

1. Bagaimana bentuk perkawinan dibawah umur yang terjadi di Kabupaten Boalemo?

2. Bagaimana dampak perkawinan dibawah umur terhadap keharmonisan rumah tangga di Kabupaten Boalemo? 


\section{B. Metode Peneltian}

Penelitian ini menggunakan metode penelitian kualitatif, yaitu penelitian yang bermaksud untuk memahami fenomena tentang apa yang dilalui oleh subyek penelitian misalnya perilaku, persepsi, motivasi, tindakan, dll, secara holistik dan dengan cara deskripsi dalam bentuk kata-kata dan bahasa, pada suatu konteks khusus yang alamiah dan dengan memanfaatkan berbagai metode ilmiah. ${ }^{1}$ Sehingga penelitian ini akan menghasilkan data yang akurat dan argumentasi yang dapat diterima serta dapat dipertanggung jawabkan. Yang paling pokok dikaji dalam penelitian ini adalah bentuk perkawinan dibawah umur dan dampaknya terhadap keharmonisan rumah tangga di Kabupaten Boalemo, sehingga penelitian ini akan mampu menjawab masalah yang diteliti.

\section{Lokasi Penelitian}

Penelitian ini dilakukan di Kabupaten Boalemo yang terdiri dari 7 Kecamatan, masing-masing Kecamatan Tilamuta, Mananggu, Botumoito, Dulupi, Paguyaman, Wonosari dan Paguyaman Pantai. Namun, yang berhasil dilakukan penelitian hanya pada 6 Kecamatan saja, 1 Kecamatan yaitu Paguyaman Pantai tidak menjadi lokasi penelitian sebab hanya ada satu kasus

perkawinan dibawah umur. Alasan pengambilan lokasi ini sebagai lokasi penelitian disebabkan oleh banyaknya kasus perkawinan anak dibawah umur yang dilakukan di Kabupaten Boalemo, dengan berbagai macam persoalan yang ada sehingga hal ini menarik untuk diteliti.

\section{Sumber Data Penelitian}

Data dapat diperoleh langsung dari lapangan termasuk laboratorium. Ini disebut sumber primer. Sumber dari bacaan disebut sumber sekunder. ${ }^{2}$ Untuk menjawab permasalahan penelitian, diperlukan sumber data melalui studi kepustakaan untuk mencari konsep-konsep, teori-teori, pendapat-pendapat, ataupun penemuan-penemuan yang berhubungan erat dengan pokok-pokok masalah. Dalam penulisan ini data yang diperlukan adalah data primer dan data sekunder, ${ }^{3}$ yang terdiri dari; hasil wawancara, data kasus, aturan perundang-undangan terkait, buku, artikel dan jurnal penelitian.

${ }^{1}$ Lexy J. Moleong, Metodologi Penelitian Kualitatif, (Bandung: PT Remaja Rosdakarya Offset, 2013), cet. 31 .

${ }^{2}$ S. Nasution, Metode Research (Penelitian Ilmiah), (Jakarta: PT Bumi Aksara, 2014), cet. 14 , h. 143.

${ }^{3}$ Amiruddin, Zainal Asikin, Pengantar Metode Penelitian Hukum, (Jakarta: PT Raja Grafindo Persada, 2004), h. 31. 


\section{Pendekatan Penelitian}

Pendekatan penelitian yang digunakan dalam penelitian ini adalah pendekatan yuridis sosiologis. Pendekatan yuridis sosiologis adalah mengidentifikasi dan mengkonsepsi hukum sebagai institusi sosial yang rill dan fungsional dalam sistem

kehidupan yang nyata. ${ }^{4}$ Selain itu, pendekatan yuridis sosiologis merupakan penelitian yang dilakukan terhadap keadaan nyata masyarakat atau lingkungan masyarakat dengan maksud dan tujuan untuk menemukan fakta (fact-finding),yang kemudian menuju pada identifikasi (problem-identification) dan pada akhirnya menuju kepada penyelesaian masalah (problemsolution $)^{5}$ Pendekatan yuridis sosiologis lebih menekankan pada penelitian yang bertujuan memperoleh pengetahuan hukum secara empiris dengan jalan terjun langsung pada obyek penelitian yaitu untuk mengetahui praktek perkawinan dibawah umur dan dampaknya terhadap keharmonisan rumah tangga di Kabupaten Boalemo.

\section{Metode Pengolahan dan Analisa Data}

Pengolahan dan analisis data adalah upaya yang dilakukan dengan jalan bekerja dengan data, memilih dan memilahnya menjadi satuan yang dapat dikelola, mensintesiskannya, dikelola dan menemukan pola, menemukan apa yang penting dan apa yang dipelajari, dan memutuskan apa yang dapat diceritakan. ${ }^{6}$

Data yang telah diperoleh, selanjutnya dilakukan pemeriksaan dan pengkajian lebih dalam untuk menjamin keakuratan data dan dapat dipertanggung jawabkan sesuai dengan aturan, teori dan konsep. Kemudian dilakukan pembahasan, pemeriksaan dan pengelompokan ke dalam bagian-bagian tertentu untuk diolah menjadi data informasi. Hasil analisa data akan diinterpretasikan untuk menjawab persoalan dalam rumusan masalah dalam penelitian ini dan diharapkan dapat memperluas wawasan khususnya dalam bidang hukum keluarga.

${ }^{4}$ Lexy J. Moleong, Metodologi Penelitian Kualitatif, (Bandung: PT Remaja Rosdakarya Offset, 2013), cet. 31.

${ }^{5}$ Lexy J. Moleong, Metodologi Penelitian Kualitatif, h. 31.

${ }^{6}$ Lexy J. Moleong, Metodologi Penelitian Kualitatif, h. 31. 


\section{Pembahasan}

\section{Bentuk Perkawinan Dibawah Umur Yang Terjadi Di Kabupaten Boalemo}

Penelitian yang dilakukan di Kabupaten Boalemo tentang Praktik perkawinan dibawah umur dan dampaknya terhadap keharmonisan rumah tangga, berhasil menemukan fakta untuk menjawab permasalahan yang diteliti. Dalam data perkawinan dibawah umur yang terjadi di Kabupaten Boalemo sejak tahun 2010 sampai dengan tahun 2016, dari 59 kasus perkawinan dibawah umur yang ada di Kabupaten Boalemo, terdapat 36 kasus perkawinan dibawah umur yang berhasil di wawancarai.

Berdasarkan hasil temuan dilapangan dalam proses penelitian terungkap beberapa fakta tentang bentuk perkawinan dibawah umur yang dilakukan di Kabupaten Boalemo antara lain:

\section{Perkawinan Melalui Proses Dispensasi Nikah Di Pengadilan Agama}

Proses dispensasi nikah yang banyak dilakukan di Pengadilan Agama merupakan wujud perhatian dan ketaatan masyarakat terhadap proses pelaksanaan perkawinan dibawah umur dalam rangka melindungi dan memberikan status yang jelas terhadap perkawinan. Sebab, perkawinan dibawah umur tanpa dispensasi nikah akan menjadi perkawinan yang tidak sah dalam hukum negara di Indonesia karena tidak terdaftar. Tentang batas umur perkawinan di Indonesia pada pasal 7 ayat (1) disebutkan: ,Perkawinan hanya diizinkan jika laki-laki sudah mencapai umur 19 (sembilan belas) tahun dan perempuan sudah mencapai umur 16 (enam belas) tahun '. Dan dalam ayat (2) disebutkan: ,Dalam hal penyimpangan terhadap ayat (1) pasal ini dapat meminta dispensasi kepada pengadilan dan Pejabat lain, yang ditunjuk oleh kedua orang tua pihak pria maupun wanita. Pasal inilah yang menjadi salah satu dasar pelaksanaan dispensasi nikah dalam perkawinan dibawah umur.

Data perkawinan dibawah umur dalam Penelitian ini, yang diangkat sebagai obyek penelitian adalah data perkawinan dibawah umur yang terdaftar dan telah melalui proses dispensasi nikah di Pengadilan Agama Tilamuta. Data ini diambil untuk

memudahkan penelusuran terhadap perkawinan dibawah umur yang terjadi di Kabupaten Boalemo, sebab ada banyak perkawinan dibawah umur yang dialakukan di Kabupaten Boalemo tetapi dilakukan dengan cara yang tidak terdaftar sehingga sangat sulit untuk melakukan penelusuran terhadap perkawinan semacam ini.

Berdasarkan hasil penelitian yang telah dilakukan, menunjukan bahwa ternyata dispensasi nikah tidak sepenuhnya dilakukan dengan cara yang baik dan benar. Sebab, ada beberapa permasalahan yang justru muncul dalam proses dispensasi nikah di Pengadilan Agama Tilamuta antara lain dispensasi nikah dilakukan setelah perkawinan dilangsungkan, dispensasi nikah memberatkan orang tua pelaku perkawinan dibawah umur dan rekomendasi dispensasi nikah yang tidak disampaikan ke KUA sebagai tempat untuk mendaftarkan perkawinan sehingga ada yang sudah melakukan dispensasi nikah tetapi akhirnya tidak terdaftar dan tidak memiliki buku nikah hingga saat ini. 
Tabel 1

Kondisi Dispensasi Nikah Dalam Perkawinan

dibawah umur

Di Kabupaten Boalemo

\begin{tabular}{|c|c|c|c|c|c|}
\hline \multirow[b]{2}{*}{ Tahun } & \multirow[b]{2}{*}{$\begin{array}{l}\text { Jumlah } \\
\text { Perkara }\end{array}$} & \multicolumn{4}{|c|}{ Kondisi Dispensasi Nikah } \\
\hline & & $\begin{array}{c}\text { Nikah } \\
\text { Sebelum } \\
\text { Dispensasi }\end{array}$ & $\begin{array}{l}\text { Dispensasi } \\
\text { Nikah Tdk } \\
\text { Disampaika } \\
\text { n Ke KUA }\end{array}$ & $\begin{array}{l}\text { Mengakib } \\
\text { atkan } \\
\text { Persidang } \\
\text { an } \\
\text { Lainnya }\end{array}$ & $\begin{array}{c}\text { Dilakukan } \\
\text { Sesuai } \\
\text { Prosedur }\end{array}$ \\
\hline 2010 & 2 & 1 & - & - & 1 \\
\hline 2011 & 3 & 1 & - & - & 2 \\
\hline 2012 & 5 & 1 & 1 & 1 & 2 \\
\hline 2013 & 5 & 1 & 1 & - & 3 \\
\hline 2014 & 5 & - & 2 & - & 3 \\
\hline 2015 & 4 & 1 & - & - & 3 \\
\hline 2016 & 12 & 2 & 1 & 2 & 8 \\
\hline Total & 36 & 7 & 5 & 3 & 23 \\
\hline
\end{tabular}

Data ini menunjukan bahwa proses dispensasi nikah yang telah dilakukan di Pengadilan Agama Tilamuta sebenarnya sudah merupakan langkah yang sangat baik dalam melindungi hak anak dalam pelaksanaan perkawinan yang sah. Namun, ternyata masih ada juga yang tidak taat dengan aturan yang telah diatur dalam proses dispensasi nikah seperti perkawinan yang dilakukan sebelum proses dispensasi nikah dikeluarkan oleh Pengadilan Agama, dari 7 kasus perkawinan semacam ini rata-rata mengakui bahwa hal ini dilakukan karena ketidaktahuan terhadap aturan yang ada dan merupakan tindakan penyelamatan terhadap anak yang akan menikah, karena saat itu sudah dalam keadaan hamil dan dikhawatirkan anak yang berada dalam kandungan akan lahir sebelum proses perkawinan. 
Mudahnya proses dispensasi nikah nampaknya mampu meningkatkan permohonan dispensasi nikah setiap tahunnya di Pengadilan Agama Tilamuta, semua proses permohonan dispensasi nikah di Pengadilan Agama Tilamuta berdasarkan hasil observasi memang dapat dikabulkan dengan mudahnya, selama proses yang dilalui pihak pemohon sesuai dengan prosedur, ada beberapa kasus yang sempat di tolak atau tidak dikabulkan hanya karena persoalan administrasi saja, misalnya ketidakhadiran pemohon dalam sidang dan pemohon yang mengajukan bukan orang tua atau wali anak. Kenyataan di lapangan ternyata beberapa kasus yang sempat di tolak dan dinyatakan gugur permohonan dispensasi nikah oleh Pengadilan Agama Tilamuta telah melakukan perkawinan tidak tercatat karena persoalan dispensasi nikah. Dengan demikian berapa pun umur yang akan menikah selama prosesnya sesuai prosedur dan dinilai sudah layak oleh hakim maka dispensasi bisa dikabulkan.

\section{Perkawinan Dengan Usia Terendah}

Perkawinan dibawah umur yang terjadi di Kabupaten Boalemo memang memiliki keragaman dan keunikan tersendiri, terutama dalam hal kondisi umur pelaku perkawinan dibawah umur. Berdasarkan aturan dalam KHI pasal 15 ayat 1 dan UU No 1 Tahun 1974 tentang Perkawinan pasal 7 ayat 1, sama-sama memberikan standar umur dalam perkawinan adalah 16 tahun untuk perempuan dan 19 tahun untuk laki-laki. Namun, dalam pasal 7 ayat 2 menegaskan bagi yang tidak mencapai standar umur diatas boleh mengajukan dispensasi ke pengadilan yang diajukan oleh orang tua baik orang tua perempuan maupun laki-laki, sebagai syarat untuk memperoleh perkawinan yang tercatat.

Mengenai kondisi umur pada saat terjadinya perkawinan dibawah umur di Kabupaten Boalemo seperti apa yang ada dalam gambar diatas, termasuk perkawinan yang tidaklah layak untuk dilakukan kalau di pikirkan secara akal sehat manusia, Sebab, terdapat anak yang menikah di usia 11 s/d 13 tahun dan bahkan ada yang masih duduk di bangku SD. Tetapi karena adanya aturan dalam undang-undang dan KHI yang berlaku di Indonesia untuk mengatur proses perkawinan, yang secara tidak langsung membolehkan perkawinan tersebut, maka perkawinan pun terjadi. Hal lain yang menyebabkan perkawinan dibawah umur karena memang rendahnya pemahaman orang tua dan pelaku itu sendiri terhadap dampak yang ditimbulkan akibat dari perkawinan di usia yang masih terlalu muda, seperti apa yang terjadi pada kasus perkawinan berikut ini.

Bagaimana mungkin rumah tangga akan bahagia kalau di dalam rumah tangga sepasang suami istri masih dalam proses belajar dalam berumah tangga, tanpa bekal ilmu dan tanpa bekal pendidikan yang layak, mengingat hidup di zaman sekarang ini pendidikan yang lebih diutamakan, untuk mendapatkan pekerjaan dan penghidupan yang layak. Perkawinan dengan usia yang masih sangat muda ini, dengan mengorbankan masa muda, pendidikan dan masa depan memang menimbulkan kekhawatiran banyak pihak.

Kekhawatiran ini muncul disebabkan oleh faktor umur yang dirasa belum layak anak yang masih sangat muda sudah mengemban tugas dan tanggung jawab sebagai ibu rumah tangga dan sebagai kepala rumah tangga, begitu pula dengan kehidupan anak-anaknya nanti yang bisa jadi didikannya pun tidak dilakukan secara maksimal dan terarah. Dengan demikian keharmonisan rumah tangga dari perkawinan dibawah umur ini tidak akan terjalin dengan baik. 


\section{Perkawinan Dengan Perempuan/Laki-Laki Yang Lebih Tua}

Ukuran kedewasaan seseorang memang tidak hanya di lihat dari berapa umurnya saat ini, tetapi juga dapat di lihat dari berbagai macam aspek yang mempengaruhi tingkat kedewasaan seseorang, antara lain dari cara berfikirnya. Perkawinan dibawah umur yang terjadi di Kabupaten Boalemo memang sangat beragam permasalahannya hingga menyebabkan perkawinan dibawah umur itu mudah terjadi. Perkawinan di usia yang telah mapan dan dewasa sangatlah dianjurkan dengan alasan demi keutuhan rumah tangga, meminimalisir terjadinya kekerasan dalam rumah tangga dan meminimalisir terjadinya perceraian, sebab perkawinan di usia yang masih sangat muda sangat rentan terjadinya masalah yang diakibatkan oleh tingkat berfikir yang masih sangat labil. Namun, saat ini tak dapat dipungkiri lagi perkawinan dibawah umur yang terjadi di Kabupaten Boalemo sebagai bukti bahwa hal itu tidak berlaku lagi. Berdasarkan hasil penelitian, ada hal menarik terjadi dalam perkawinan dibawah umur di Kabupaten Boalemo yaitu perkawinan dibawah umur dengan salah satu pasangan yang lebih tua. Perkawinan semacam ini sebenarnya merupakan sesuatu hal yang biasa terjadi dan masih dalam tataran yang normal-normal saja, tetapi dalam pembahasan ini ada sedikit berbeda dengan kejadian yang biasanya terjadi yaitu dua kasus perkawinan antara perempuan di bawah umur dengan laki-laki yang lebih tua dengan rentan umur yang cukup jauh antara 23-25 tahun, kemudian ada dua kasus perkawinan dibawah umur antara laki-laki dibawah umur dengan perempuan yang lebih tua dengan rentan umur yang tidak terlalu jauh hanya 3 tahun.

Zaman sekarang ini masalah rumah tangga akan muncul disaat masing-masing tidak mampu mengimbangi kehidupan rumah tangganya, baik dari tingkat kedewasaan berfikir, tingkat ekonomi maupun tingkat emosionalnya. Dalam berumah tangga bisa jadi pasangan yang lebih dewasa akan lebih memahami pasangannya yang masih dibawah umur, mereka akan merasa lebih disayangi dan merasa nyaman disebabkan oleh sikap pasangan yang lebih tua menjadi pelindung bagi dirinya. Sehingga kehidupan rumah tangga perkawinan semacam ini akan terhindar dari kekerasan dalam rumah tangga dan akan terjalin harmonisasi dalam rumah tangganya.

4. Seks Bebas Sebelum Perkawinan Perkawinan merupakan perintah agama

bagi orang yang sudah mampu untuk melaksanakannya baik mampu secara lahir maupun bathin. Dengan perkawinan orang akan terhindar dari perbuatan zina dan seks bebas diluar perkawinan, hal ini sesuai dengan salah satu tujuan perkawinan yang didalamnya menjelaskan bahwa perkawinan merupakan jalan alami dan biologis untuk menyalurkan dan memuaskan hasrat seksual seseorang sekaligus mampu menjaga pandangan mata, menenangkan jiwa dan mampu menjaga dari perbuatan yang terlarang.

Perkawinan dibawah umur yang terjadi di Kabupaten Boalemo hampir rata-rata dilakukan disebabkan oleh seks bebas sebelum perkawinan hingga menyebabkan perempuan hamil di luar nikah, hasil dari perbuatan terlarang berupa perilaku seks 
bebas dan berhubungan seks layaknya suami istri yang dapat dikategorikan sebagai perzinahan. Hal ini banyak dilakukan oleh sebagian remaja dibawah umur yang belum layak untuk menikah di Kabupaten Boalemo yang akhirnya banyak merugikan diri sendiri.

Tabel 2

Data Perkawinan Dibawah Umur Yang Melakukan Seks Bebas Sebelum Perkawinan

\begin{tabular}{|c|c|}
\hline Kondisi & Jumlah \\
\hline Hamil & 25 \\
\hline Tidak Pernah & 3 \\
Melakukan & \\
\hline Pernah & 8 \\
Melakukan & 36 \\
\hline Total & \\
\hline
\end{tabular}

Perkawinan hamil di luar nikah sebagai akibat dari terjadinya perbuatan asusila bukanlah sesuatu hal yang baru lagi dalam proses perkawinan saat ini, karena perkawinan semacam ini dimana-mana pasti ada kejadian yang sama. Walaupun begitu, hal ini masih tetap menjadi masalah serius yang harus dipecahkan untuk mendapatkan titik terang dan solusi terbaik agar mampu meminimalisir perkawinan semacam ini. Kehadiran undang-undang atau aturan lainnya di Indonesia masih terlalu lemah dan terkesan tidak tegas dalam meminimalisir terjadinya perkawinan karena hamil di luar nikah. Padahal yang lebih banyak menjadi korban dalam kejadian ini adalah anak-anak yang masih belum layak untuk dinikahkan dan masih butuh perlindungan secara hukum.

Perbuatan asusila dan perilaku seks bebas pada anak-anak sudah selayaknya mendapatkan perhatian serius dari pemerintah untuk mencarikan solusi yang tepat dalam mengatasi masalah ini. Kalau rata-rata perilaku seperti ini bisa diselesaikan dengan cara menikahkan, hal ini tidak akan efektif karena justru hanya akan memanjakan para pelaku yang berfikir kalau sudah terjadi sesuatu pasti jalan terakhir akan dinikahkan juga.

Dengan begitu mereka akan semakin nyaman melakukan perbuatan yang seharusnya dilarang, masih lebih baik kalau pelaku berbuat semacam ini hamil dan kemudian dinikahkan tetapi bagamana dengan pelaku lainnya yang tidak hamil tetapi sering melakukan perbuatan terlarang, maka perkawinan tidak terjadi tetapi penderitaan berkeanjangan pada anak akan lama dirasakannya.

5. Perkawinan Tanpa Restu Orang Tua Perkawinan pada dasarnya merupakan 
Sesuatu ikatan suci antara seorang laki-laki dan perempuan dan wajib untuk dipublikasikan kepada khalayak demi menghindari pandangan buruk terhadap perkawinan yang tidak di publikasikan. Restu orang tua dalam sebuah ikatan perkawinan merupakan salah satu penentu baik buruknya hubungan rumah tangga setelah perkawinan. Terkadang ada orang tua yang cukup keras dalam melarang perkawinan dibawah umurnya karena status sosialnya yang tidak sama, karena alasan pendidikan dan karena menganggap belum layak untuk menikah di usia yang masih terlalu muda. Kejadian semacam ini terjadi di Kabupaten Boalemo di 4 kasus perkawinan dibawah umur yang tanpa restu orang tua salah satu pihak.

Munculnya wali adhol yang berawal dari tidak adanya restu orang tua dalam perkawinan tersebut diatas, sebenarnya tidak bisa disalahkan sepenuhnya kepada anak-anak yang sudah sepakat melangsungkan perkawinan. Peran orang tua sebenarnya harus dipertanyakan dalam hal ini, kenapa nanti pada saat mendekati perkawinan baru menyatakan diri tidak setuju, padahal sebelumnya membiarkan anaknya bebas melakukan apa saja yang ia inginkan. Orang tua seharusnya melakukan instrospeksi diri ketika terjadi hal semacam ini, sejauh mana proses pengawasannya, perhatiannya dan peranannya dalam menjaga anak-anaknya hingga kejadian ini terjadi bukan malah menyalahkan sepenuhnya kepada anak-anaknya.

\section{Dampak Perkawinan Dibawah Umur Terhadap Keharmonisan Rumah Tangga}

Perkawinan dibawah umur yang banyak terjadi di tengah-tengah masyarakat khusunya di Kabupaten Boalemo, memberikan gambaran yang sebenarnya tentang realitas perkawinan dibawah umur yang banyak memberikan dampak negatif terhadap keharmonisan rumah tangga pelaku perkawinan dibawah umur. Kehidupan rumah tangga yang seharusnya bahagia, rukun dan damai justru tidak selamanya tercapai sesuai harapan banyak orang yang melakukannya. Pemahaman terhadap aturan hukum keluarga yang dalam hal ini mengatur tentang perkara perdata antara lain perkawinan dan juga faktor umur yang masih sangat muda untuk menjalani kehidupan rumah tangga, bisa jadi merupakan bagian dari faktor yang menyebabkan tidak tercapainya tujuan perkawinan.

Berdasarkan hasil penelitian yang dilakukan untuk menguku tingkat keharmonisan rumah tangga dalam perkawinan dibawah umur di Kabupaten Boalemo, maka digunakan instrumen penelitian dengan menggunakan angket yang disebar kepada para pelaku perkawinan dibawah umur. Dari total 36 kasus perkawinan dibawah umur yang diteliti dibagi menjadi dua kelompok, kelompok yang pertama merupakan kelompok yang telah berpisah dengan pasangannya sebanyak 8 kasus, sehingga dapat dipastikan bahwa kelompok ini rumah tangganya memang sudah tidak harmonis lagi. Kemudian kelompok kedua sebanyak 28 kasus yang masih hidup bersama sampai saat ini. Dengan demikian kelompok kedua yang menjadi fokus dalam sebaran angket untuk mengukur tingkat keharmonisan rumah tangga. Hasil sebaran angket ini dapat terungkap fakta bahwa perkawinan dibawah umur dapat memberikan dampak negatif yang cukup besar terhadap keharmonisan rumah.

Keharmonisan rumah tangga dapat diukur berdasarkan 3 faktor pendukung tercapainya keharmonisan dalam rumah tangga yaitu; 1) Faktor kesejahteraan jiwa, 2) Faktor kesehatan, dan 3) Faktor ekonomi rumah tangga. Ketiga faktor ini saling mendukung antara satu dengan 
Jurnal IImiah AI-Jauhari (JIAJ)

Studi Islam dan Interdisipliner

Volume 3 No 2 September 2018

ISSN 2541-3430 E-ISSN 2541-3449

yang lainnya sehingga kalau salah satunya saja ada yang lemah dalam rumah tangga maka dapat dinilai bahwa 


\section{PENUTUP}

\section{Kesimpulan}

Setelah dilakukan penelitian pada obyek penelitian dalam proses perkawinan dibawah umur, maka dapat disimpulkan bahwa, praktek perkawinan dibawah umur dan dampaknya terhadap kehidupan rumah tangga di Kabupaten Boalemo adalah sebagai berikut:

1. Bentuk perkawinan dibawah umur yang terjadi di Kabupaten Boalemo berdasarkan hasil wawancara dalam

proses penelitian ini berhasil menemukan ada 5 (lima) bentuk perkawinan dibawah umur yang

menjawab permasalahan dalam penelitian ini, yaitu; 1) Perkawinan dilakukan melalui proses dispensasi nikah di Pengadilan Agama. 2) Perkawinan dengan usia terendah. 3) Perkawinan dengan laki-laki/perempuan yang lebih tua. 4) Seks bebas sebelum perkawinan. 5) Perkawinan tanpa restu orang tua, Bentuk perkawinan yang telah dibahas ini merupakan bentuk-bentuk perkawinan dibawah umur yang banyak di praktekan dalam masyarakat Kabupaten Boalemo.

2. Adapun dampak perkawinan dibawah umur di Kabupaten Boalemo berdasarkan hasil penelitian yang dilakukan melalui proses observasi, wawancara dan sebaran kuisioner pada responden pelaku perkawinan dibawah umur ditemukan faktor-faktor dalam perkawinan dibawah umur setelah proses perkawinan terjadi yang sangat mempengaruhi tingkat keharmonisan rumah tangga, yaitu; 1) Faktor kesehatan, hal ini merupakan faktor yang mempengaruhi tingkat kesejahteraan secara fisik. 2) Faktor kesejahteraan

jiwa, ketidakharmonisan rumah tangga pada faktor kesejahteraan jiwa dapat dilihat dari beberapa instrumen yang menunjukan, tingginya frekuensi

pertengkaran dan percekcokan, adanya kekerasan dalam rumah tangga, seringnya terjadi perbedaan pendapat. dan 3) Faktor ekonomi

rumahtangga,dimanajika

pendapatan dan pengeluaran berimbang maka kehidupan rumah tangga pun akan terasa nyaman dan damai, namun jika pengeluaran lebih besar dari pada penghasilan yang didapatkan maka akan sangat mempengaruhi proses dalam berumah tangga. Ketiga faktor ini menjadi tolok ukur keharmonisan rumah tangga, yang saling terkait antara satu

dengan yang lainnya, sehingga apabila salah satu tidak tercapai maka rumah tangga dapat dikategorikan sebagai rumah tangga yang tidak harmonis. Keharmonisan rumah tangga akan mampu tercapai dengan baik jika perkawinan berjalan dengan baik tanpa masalah.

\section{B. Rekomendasi}


Untuk mewujudkan ketertiban dan ketaatan hukum dalam proses perkawinan dibawah umur tentunya banyak hal yang harus dibenahi dalam proses ini terutama dalam rangka perbaikan aturan yang berlaku, ketegasan terhadap aturan yang ada dan juga peningkatan kesadaran masyarakat khususnya remaja dan orang tua. Sehingga berdasarkan hasil penelitian yang telah dilakukan dapat memberikan rekomendasi sebagai masukan positif demi terwujudnya tata aturan hukum yang lebih baik, antara lain:

1. Penting melakukan revisi terhadap Undang-Undang No. 1 Tahun 1974 tentang Perkawinan, khususnya pada pasal 7 dan KHI pasal 15 tentang batasan usia perkawinan, harapannya bisa lebih tegas lagi dalam pemberian batasan usia perkawinan dengan tidak memberikan keleluasaan melalui proses dispensasi nikah, dengan demikian proses dispensasi nikah hanya dapat diberikan kepada pelaku perkawinan dengan usia yang sudah ditentukan, dan kalau hal tersebut masih dilanggar maka sebaiknya ada sangsi yang tegas sehingga mampu mengurangi perkawinan dibawah umur yang banyak terjadi.

2. Perlunyakerjasamaantara

Kementerian Agama, Dinas Kesehatan, Dinas Pendidikan dan juga para penegak aturan dalam hal ini Kejaksaan, Kepolisian, Pengadilan dan lainnya, untuk bekerja sama melakukan proses sosialisasi, edukasi, penyadaran dan pembinaan di kalangan remaja pra nikah atau usia sekolah terhadap bahaya perkawinan dibawah umur, agar perkawinan dibawah umur mendapatkan perlindungan hukum akibat dari

kekerasanseksual,KDRT, penelantaran dan keberlanjutan pendidikan anak.

3. Lebih memperhatikan prosesi adat perkawinan yang dilakukan dalam proses perkawinan dibawah umur, sebab terdapat prosesi perkawinan dibawah umur yang dilakukan tidak sesuai dengan tata aturan adat yang sebenarnya, yang bisa jadi hanya akan merusak kesakralan dari sebuah prosesi adat. Sehingga seharusnya dalam proses perkawinan wanita hamil tidak dilaksanakan dengan menggunakan prosesi adat sebagai hukuman adat terhadap pelaku perkawinan yang melanggar ketentuan adat. 


\section{DAFTAR PUSTAKA}

AbuSyuqqah, Abd. Halim, Kebebasan Wanita, (Jakarta: Gema Insani, 1999).

Al-Asqolani, Ibnu Hajar, Fathul Ba "an, Penjelasan Kitab Shahih Al-Bukhori jilid 15, (Jakarta: pustaka Azzam, 2006).

Al ‘Ati, Mahmudah ‘Abd., Keluarga Muslim, (Surabaya: Bina Ilmu, 1984).

Al-Batawy, Saiful Anwar, Rahasia Rumah Tangga Harmonis Seperti Rasul, (Jakarta: Kunci Iman, 2012).

Al-Buthi, Muhammad Said Ramadhan, Perempuan Dalam Pandangan Hukum Barat dan Islam, (Yogyakarta: Suluh Press, 2005).

Al-Kuthbi, Moh. Habib, Tesis: Dampak Perkawinan Dibawah Umur Terhadap Hubungan Dalam Rumah Tangga. (Yogyakarta: UIN Sunan Kalijaga, 2016).

As-Subki, Ali Yusuf, Fiqh Keluarga Pedoman Berkeluarga Dalam Islam, (Jakarta: Sinar Grafika Offseet, 2010).

Amiruddin, Asikin, Zainal, Pengantar Metode Penelitian Hukum, (Jakarta: PT Raja Grafindo Persada, 2004).

Basri, Hasan, Merawat Cinta Kasih. (Yogyakarta: Pustaka Pelajar, 1996).

Basyir, Ahmad Azhar, Hukum Perkawinan Islam, (Cet. 9, Yogyakarta: UII Press, 2000).

Cansil, C.S.T, Pengantar Ilmu Hukum dan Tata Hukum Indonesia, Cet. VIII (Jakarta: Balai Pustaka, 1989).

Departemen Agama RI, Al-Qur'an dan Terjemah ,Mushaf Fatimahe, (Jakarta: Pustaka AlFatih, 2009).

Departemen Agama RI, Pedoman Pelaksanaan Pendidikan Agama Islam, (Jakarta: 1985/1986).

Ghazaly, Abd. Rahman, Fiqih Munakkahat, (Jakarta: Kencana, 2006).

Hamdani, Risalah Al-Munakkahah, (Jakarta: Citra Karsa Mandiri, 1995).

Hanafi, Yusuf, Kontroversi Pernikahan Anak di Bawah Umur, (Mandar Maju, 2011)

Instruksi Presiden Nomor 1 Tahun 1991 Tentang Kompilasi Hukum Islam di Indonesia.

Irfan, Lukman A., Seri Tuntutan Praktis Nikah, (Yogyakarta: Mitra Pustaka, 1997).

Ishak, Ajub, Hukum Perdata Islam Di Indonesia Dan Praktek Perkawinan Dalam Bingkai Adat Gorontalo, (Cet. I, Gorontalo: Sultan Amai Press, 2014). 
J. Moleong, Lexy, Metodologi Penelitian Kualitatif, (Bandung: PT Remaja Rosdakarya Offset, 2013).

Jahar, Asep Saepudin, Nurlaelawati, Euis, dan Arifin, Jaenal Hukum Keluarga, Pidana Dan Bisnis, (Cet. I, Jakarta: Kencana, 2013).

Junaidi, Dedi, Bimbingan Perkawinan Membina Keluarga Sakinah Menurut Al-Quran Dan As-Sunah, (Cet. I, Jakarta:Akademika Presindo 2000).

Khallaf, Abd. Wahab, Kaidah-Kaidah Hukum Islam, Ilmu Ushul Fiqih, alih bahasa Noer Iskandar al Barsany, Moh. Tolchah Mansoer, Ed. I., Cet. VII (Jakarta: Raja Grafindo Persada, 2002).

Kamal, Abu Malik, Fiqih Sunnah Wanita, (diterjemahkan oleh Ghozi. M), (Cet. I, Bandung: Cordoba Internasional Indonesia, 2016).

Kau, Sofyan A.P., Cara Mudah Menulis Proposal Skripsi Dan Tesis, (Gorontalo: Sultan Amai Press, 2016).

Kuzairi, Achmad, Nikah Sebagai Perikatan, (Jakarta: Raja Grafindo Persada, 1995).

Lamintang, P.A.F., dan Lamintang, Theo, Kejahatan Melanggar Norma Kesusilaan dan Norma Kepatutan, (Jakarta: Sinar Grafika, 2011).

Mazhari, Husain, Membangun Surga Dalam Rumah Tangga, (Bogor: Cahaya, 2004).

Manan, Abdul, Aneka Masalah Hukum Perdata Islam Di Indonesia, (Cet. IV, Jakarta: Prenada Media Grup, 2014).

Muhandid, Husen, Fiqh Perempuan, Refleksi Kyai atas Wacana Agama \& Gender , (Yogyakarta: Kerta.LKIS, 2001)

Mulia, Siti Musda, Membangun Surga Di Bumi ,Kiat-Kiat Membina Keluarga Ideal Dalam Islam ; (Jakarta: Gramedia, 2011).

Muthiah, Aulia, Hukum Islam Dinamika Seputar Hukum Keluarga, (Cet. I, Yogyakarta: Pustaka Baru Press, 2017).

Nasution, S., Metode Research (Penelitian Ilmiah), (Jakarta: PT Bumi Aksara, 2014).

Nirwana, Ade Benih, Psikologis Kesehatan Wanita, (Yogyakarta: Nuha Medika, 2011).

Purbasari, Indah, Hukum Islam Sebagai Hukum Positif Di Indonesia ,Suatu Kajian di Bidang Hukum Keluarga,(Malang: Setara Press, 2017).

Qaimi, Ali, Menggapai Langit Masa depan Anak, (Bogor: Cahaya, 2002).

Rajafi, Ahmad, Nalar Hukum Keluarga Islam Di Indonesia, (Cet. I, Yogyakarta: Istana Publishing, 2015).

Ramulyo, Moh. Idris, Hukum Perkawinan Islam, (Jakarta: Sinar Grafika Offset, 1999). 
Republik Indonesia, Undang-Undang Nomor 1 Tahun 1974 Tentang Perkawinan.

Republik Indonesia, Peraturan Pemerintah No. 9 Tahun 1975, tentang aturan pelaksanaan Undang-Undang Perkawinan.

Republik Indonesia, Undang-Undang No. 35 tahun 2014 tentang Perlindungan Anak, perubahan atas Undang-Undang Nomor 23 Tahun 2002 tentang Perlindungan Anak.

Rofiq, Ahmad, Hukum Perdata Islam Di Indonesia, (Cet. I, Jakarta: Rajawali Pers, 2013).

Sabiq, Sayyid, Fiqih Sunnah, (Bandung: PT. Al-Ma'arif, Juz IV, 2000).

Simorangkir, J.C.T., Erwin, Rudy T., Prasetyo, J.T., Kamus Hukum, Cet. VI (Jakarta: Sinar Grafika, 2007 
Jurnal IImiah Al-Jauhari (JIAJ)

Studi Islam dan Interdisipliner

Volume 3 No 2 September 2018

ISSN 2541-3430 E-ISSN 2541-3449 